NBER WORKING PAPER SERIES

\title{
EXPLAINING DOMESTIC CONTENT: EVIDENCE FROM JAPANESE AND U.S. AUTO PRODUCTION IN THE U.S.
}

Deborah L. Swenson

Working Paper 5495

\author{
NATIONAL BUREAU OF ECONOMIC RESEARCH \\ 1050 Massachusetts Avenue \\ Cambridge, MA 02138 \\ March 1996
}

\footnotetext{
Prepared for the NBER conference, "Effects of Trade Protection and Promotion Policies," October 6-7, 1995. This paper is part of NBER's research program in International Trade and Investment. Any opinions expressed are those of the author and not those of the National Bureau of Economic Research.

(C) 1996 by Deborah L. Swenson. All rights reserved. Short sections of text, not to exceed two paragraphs, may be quoted without explicit permission provided that full credit, including (C)
notice, is given to the source.
} 


\title{
EXPLAINING DOMESTIC CONTENT: \\ EVIDENCE FROM JAPANESE AND U.S. \\ AUTO PRODUCTION IN THE U.S.
}

\begin{abstract}
This paper studies the domestic content decisions of auto makers in the U.S. between 1984 and 1993 using foreign trade zone activity as a tool by which one can observe individual sourcing and production. The results show that although the domestic content of Japanese firms is rising, differences are not being eliminated completely. Also, the apparent elasticity of substitution is lower for Japanese than for U.S. firms. These results suggest that although transplant production may reduce the U.S. automotive deficit with Japan, transplant production will not cause its elimination.
\end{abstract}

Deborah L. Swenson

Department of Economics

University of California

Davis, CA 95616

and NBER 


\section{Explaining Domestic Content: Evidence from Japanese and U.S. Auto Production in the U.S.}

\section{Introduction}

The ongoing U.S. trade deficit in automobiles and auto parts remains a central focus of trade disputes between the U.S. and Japan. There are many margins on which this deficit could change. These include export volumes, production location and domestic product content. However, this deficit has continued, despite large changes in the assembly pattern of U.S. purchased autos. For example, in 1994 the U.S. purchased 2.69 million Japanese name plate automobiles. This was roughly the same number as the 2.78 million purchased in 1990 . However 1.45 million, or 54 percent of those vehicles sold in 1994 were assembled in U.S. transplant operations as compared with only 38 percent 4 years earlier. In light of the shift in production, the apparent immobility of the automotive deficit raises the question as to whether multinational production arrangements, such as automobile transplant production in the U.S., ultimately have any effect on the trade balance between nations. In particular, these facts raise the question whether the national identity of the firms, as opposed to production location alone, determines international sourcing decisions. This paper begins to address this question by studying the production of U.S. and foreign auto firms in U.S. foreign trade zones.

Although roughly 30 percent of imports arrive through the intra-firm trade of multinationals, and the percentage is much higher in the auto industry, there has been little examination of the factors shaping these flows and firm decisions. Among theoretical treatments of this issue, considerations of factor costs, increasing returns to scale in production, contracting difficulties, and the circumvention of 
protection have figured prominently in the description of motivations for multinational activity.' Indeed, these rationales are not necessarily exclusive of each other. Unfortunately a dearth of firm level data on multinational firms' activity in trade has impeded widespread empirical observation and characterization of these effects.

This paper considers one aspect of multinational activity, the domestic content decision of U.S. and foreign auto firms in the U.S. ${ }^{2}$ Observation of this activity is facilitated by the U.S. operation of the foreign trade zones program. The evidence shows that although the domestic content of U.S. automakers is higher overall than that of Japanese auto firms, the difference is shrinking as the operations age. It should also be noted that, although Japanese manufacturers may initially have located in the U.S. for political reasons, Japanese auto assembly operations appear to be affected by relative prices, just as U.S. production facilities are. These conclusions are supported by observation of domestic input content.

The paper proceeds as follows. Section 2 discusses factors that may influence the foreign and domestic content of automobile production in the U.S. , including the institutional details of the U.S. Foreign Trade Zones program. Section 3 provides a simple model of the demand for inputs, which links the relative demand for domestic and foreign inputs to movements in factor costs. The model is then tested in section 4. Concluding comments and discussion are presented in section 5.

\footnotetext{
1 See Helpman (1984), Markusen (1984), Ethier (1986), and Bhagwati (1987) for examples of these arguments.

2 In addition to trade talks regarding Japanese sales and purchases in the automotive sector, policy concem regarding domestic content is exhibited by The American Automobile Labeling Act. This act requires that, as of the 1995 model year, vehicle stickers include information on the location of automobile assembly as well as the percentage of U.S./Canadian content. These stickers must also include the production location of the engine and transmission as well as the country of origin for all major sources of content.
} 


\section{Foreign Trade Zones: Design and Usage}

\section{2a. Trade Flows and Multinational Activity}

The predicted effect of multinational activity on trade depends largely on the international conditions that are used to construct the model for prediction. For example, Helpman and Krugman (1985) describe the effects of multinational production in the context of a conventional factor model. They demonstrate that the presence of multinational production can enhance or diminish the volume of trade. The degree of intra-industry trade that occurs in this setting depends largely on the distribution of factors. Since headquarter services are assumed to be capital intense in production, the flows of intra-firm headquarter services, however, flow in a single direction and originate from the capital abundant country. In contrast, Markusen and Venables (1995) consider an alternative framework in which multinational activities can originate from multiple locations. Firms have many potential modes of operation, including existence as a national firm which exports, or as a multinational firm that produces in many locations. When firms decide how to serve foreign markets, they must weigh the opposing forces of transport and tariff costs, which impede export sales, against the importance of scale economies in production, which raise the cost of multinational activity relative to production in a single location. In their model, multinationals initially enhance the volume of trade, but may ultimately diminish the volume of trade if the multinational form of operation becomes increasingly prevalent over time.

Since we observe elements of both models in the international environment, it is not possible to form a single prediction regarding the effect of multinationals on trade. It is likely that the ultimate effect of multinationals on trade volumes will depend on the characteristics of the industry, as well as the underlying sources of comparative advantage across countries. In this case, the overall effects have to be observed industry by industry. 
To date few studies have examined the importance of multinational firms in trade. One exception is Zeile (1995) who considers a number of measures that demonstrate the relative importance of U.S. value added, or parts in multinational production. Zeile's results are based on a panel of multinational firms operating in the U.S. This work documents that there are significant differences across industries and countries in the measures of U.S. economic activity associated with multinational firms. Zeile observes that Japanese multinationals incorporate a smaller percentage U.S. content in their U.S. production, relative to other multinationals operating in the U.S. Zeile suggest that this observed difference may reflect Japanese methods of subcontracting, as well as the relatively high portion of Japanese firm investment that was greenfield as opposed to acquisition.

An ongoing question in this literature is whether multinational activity enhances or substitutes for market service by export. In one recent analysis, Blomstrom, Lipsey and Kulchycky (1988) study the case of U.S. and Swedish headquartered multinationals and conclude that the activities are complementary. In another study, Brainard (1993) performs a cross industry analysis, in a study which describes the relative sales of multinationals generated by affiliate activity as compared with export. This work discovers that affiliate activities rise in importance with transportation costs, tariffs and other trade barriers, but that the relative importance of affiliate activities falls when it is confronted by higher barriers to foreign investment. In addition, Brainard finds that plant scale and proprietary firm assets also affect the modes of serving foreign markets, providing evidence that the relative importance of multinational activity conducted by affiliates responds to industry characteristics. In light of this characterization, this paper seeks to describe and measure the responsiveness of domestic content in the auto industry.

\section{2b. The Foreign Trade Zone Program}

Data from the U.S. foreign trade zones program forms the basis of this study. The foreign trade 
zones program was created in 1934 in an effort to encourage international trade and the reexport of products in particular. However, the program was of little use to producers until modifications were rendered in later years. In its initial form, the foreign trade zones program could not be used for production or assembly purposes. The Boggs amendment in 1950 expanded the activities that could be performed within foreign trade zones to include manufacture. A second major change was a 1980 Treasury department ruling that limited the dutiable value of products leaving foreign trade zones to the cost of the components contained in those products.

The foreign trade zones program operates along two tiers. General purpose zones are available for use by most industries. Both foreign and domestic firms are allowed to operate within these zones. However, sensitive industries, such as automobiles and steel, must operate within the more regulated foreign trade subzone program. By the end of the 1980's the auto industry accounted for more than 80 percent of all foreign trade subzone shipments.

It is no coincidence that all U.S. auto assembly plantscurrently in the U.S. have sought and obtained foreign trade subzone status. Auto assemblers benefit from three tariff reductions that are provided by operation within a foreign trade zone. The most important provision is one that enables producers to reduce the tariffs they owe in the case of "inverted tariffs". "Inverted tariffs" refer to situations in which the tariff levied on intermediate inputs is higher than the tariff applied to the import of the final product. Normally, firms utilizing imported components pay the tariffs associated with each individual component. However, if a firm produces within the boundaries of a foreign trade zone, the firm may select to pay either the tariff rate assessed on the final good, or the tariff rate that applies to the imported components. The obvious benefit is the firm's ability to select the lowest of the two rates.

Currently, the ability to reduce tariffs when an inversion exists, is lauded as a provision which helps U.S. assemblers to remain competitive with foreign assemblers. A rationale for the program is elimination of the cost disadvantages that might face U.S. assemblers who use imported components. 
Suppose, for example, that the foreign firm produces a product with foreign parts, and completes the assembly abroad. When the product is shipped to the U.S., it pays the tariff rate that applies to the assembled good. In cases of tariff inversion, a U.S. firm, performing assembly in the U.S., could pay a higher tariff on the same foreign components. This ability to circumvent "inverted tariffs" is particularly important for producers in the auto industry where the tariff rate on finished cars is $2.5 \%$ and the rate on many auto parts ranges from 4 to 11 percent. ${ }^{3}$ A further tariff benefit accruing to zone users is the ability to delay tariff payments. In general, firms must pay customs duties within 10 days of a product's entry to the U.S. However, firms located in foreign trade zones are entitled to delay payment of customs duties until 10 days after their products have left the foreign trade zone for their destination markets. The magnitude of this second benefit is proportional to inventory held within the subzone. Further, for finished products that are exported out of the U.S., no tariff is due on the imported components that were used in production. Finally, the presence of foreign trade zones provides one last benefit for automobile producers who practice just-in-time production techniques. The time required for customs is reduced by as much as 5 days, enabling firms to produce more efficiently. ${ }^{4}$

Foreign trade subzone benefits are not automatic. Automakers who wish to gain foreign trade zone status for their assembly operations are required to apply for firm level subzone status, and they are further required to renew these subzone privileges periodically. Foreign trade subzones are granted to firms, and are attached to general purpose foreign trade zones. Hence, a firm can not apply for subzone status unless there is a general purpose zone to which it can attach itself. As long as this qualification is met however, there are essentially no moving costs entailed in the creation of a foreign trade subzone. Automakers typically request that their current manufacturing facilities be given subzone

3 Inverted tariffs in the auto industry originated from U.S. tariff act of 1930.

4 Products that are sourced through foreign trade zones may move more quickly since they avoid some customs clearance formalities. 
status, and the boundaries of the subzone are defined accordingly.

In the larger context, it should be mentioned that the foreign trade zone program can not be used to circumvent other trade policies. To begin, although producers have the choice of paying the lower of the intermediate inputs tariff and the final product tariff on imported components, operations within a foreign trade zone or subzone can not be used to avoid the payment of anti-dumping duties. Further, although products that are reexported from trade zones pay no U.S. tariffs on their use of imported components, the NAFTA agreement is explicit that foreign trade zones can not be used to avoid the payment of any North American tariffs on products that are subsequently exported to Mexico or Canada.

\section{2c. Trends in Foreign Trade Zone Usage by Auto Producers}

A growing portion of trade in automobiles and auto parts enters the United States through the foreign trade zones program. By 1993, the volume of automobile trade entering foreign trade zones was over 12 billion dollars. Over half of this amount entered special purpose foreign trade subzones where domestic assembly or activity was conducted before the products were shipped for final sale. ${ }^{3}$ Table 1 displays some of the trends in automakers' usage of foreign trade zones. First, it is notable, that more than 90 percent of the zone shipments are destined for the domestic market whether the assembly is completed by a U.S. or foreign firm. However, the usage of domestic inputs by U.S. and foreign automakers differs markedly. In 1993, foreign auto firms sourced two-thirds of their inputs from the U.S., while U.S. firms sourced more than 95 percent of their inputs from the U.S. Nonetheless, the U.S. sourcing by foreign firms had grown dramatically. In 1984, foreign firms purchased only 35 percent of their inputs in the U.S.

5 Auto activity represented $51.4 \%$ of all subzone foreign receipts in 1993 . In turn, auto parts comprised $92.8 \%$ of these auto subzone foreign receipts. 
Tables $2 \mathrm{~A}$ and $2 \mathrm{~B}$ track individual firm usage of automobile foreign trade subzones. Foreign and U.S. firms exhibit a few distinct trends in their foreign trade zone operations. To begin, most domestic manufacturers had their trade zones in place by 1988 , while foreign firms were continuing to open new zones. The one exception was Volkswagen. Volkswagen opened its U.S. facility before the other foreign producers, and closed its U.S. production facility in 1988. It should also be noted that three subzones contain international joint venture activity; NUMMI, Autoalliance and Diamond-Star. ${ }^{6}$ While there is some heterogeneity in the sourcing and shipping activity between firms that are headquartered in the U.S. or abroad, the U.S. plants have uniformly higher domestic input content and shipping. Although the entry of new zone operators obscures the overall aging process of zone activity, it also appears that foreign firms use an increasing percentage of inputs sourced from the U.S.

Table 3 compares auto industry activity represented by the foreign trade zones data set of this paper with aggregate trade statistics and with other industries. It is not possible to provide an exact match, since the Department of Commerce classification system places foreign automakers under one of two different categories, rather than a single category which encompasses these firms automotive production activity. In particular, the Department of Commerce classifies each foreign firm according to its primary line of business. In this taxonomy, some automotive firms are placed under the manufacturing heading, while others are designated wholesale trade. As with manufacturing in general, the bulk of imports brought to affiliates in the transportation equipment sector are used for further manufacture. However, in contrast with the manufacturing aggregate, the transportation sector imports capital equipment in twice the proportion. Nonetheless, the transportation equipment sector imports capital equipment at the low amount of 3.5 percent of affiliate imports. The transportation sector sources a much higher percentage of its imports shipped to affiliates directly from the foreign

6 For the purposes of this paper, zones are classified as an international joint venture if the output from the zone results in automobiles sold under both U.S. and foreign nameplates. 
parent, relative to the manufacturing sector as a whole.

To date, no work has been done on the foreign trade zones program. However, work has examined the Oversees Assembly Provision (OAP). This program is similar in that it is meant to mitigate tariff-induced disadvantages faced by U.S. component makers. When the U.S. imports products, which are assembled abroad, the OAP exempts from duty that portion of the U.S. imported final products that is attributable to U.S. components. The general finding in this area, as demonstrated by Finger (1976) and Mendez (1993), is that the OAP has increased the activity of U.S. parts industries at the same time that it has reduced the activities of U.S. assemblers. ${ }^{?}$

7 Grossman (1982) shows that the OAP may actually cause intra-industry trade in homogenous products, as domestic and foreign producers may perceive differential input costs. 


\section{A model of Zone Usage}

To motivate the empirical work that follows, we construct a stylized model to describe the demand for auto components of domestic and foreign origin. For expositional ease, the notation and explanations that follow consider representative U.S. and Japanese firms that are both producing in and selling to the U.S. market. In fact, it is assumed that multinational firms exist in equilibrium at all times, although the volume of their activities may change.

Multinational firms are assumed to use both domestic and foreign inputs in their production processes according to a constant elasticity of substitution production function. The output of a typical U.S. firm $Y_{w}$, is a function of U.S. inputs $X_{w s}$ and Japanese inputs $X_{j}$. Each of the $N_{w s}$ varieties of U.S. inputs and $\mathrm{N}_{\mathrm{j}}$ varieties of Japanese inputs enter the production function symmetrically, and the elasticity of substitution between any two inputs is $\sigma$.

$$
Y_{w}=\left[N_{w} X_{w}^{(1-1 / 0)}+N, X_{j}^{(1-1 / 0)}\right]^{\frac{1}{1-1 / \omega}}
$$

Japanese firms producing in the U.S. are also expected to have a constant elasticity of substitution production function which reflects the output generated by the U.S. and Japanese inputs entered into the production process. However, since Japanese firms are headquartered in Japan, we introduce the possibility that Japanese firms use U.S. inputs less efficiently than they do Japanese inputs. ${ }^{2}$ The differential efficiency related to the use of non-Japanese inputs is captured by the term $\delta_{w}$. It is assumed that $0<\delta_{\mathrm{us}}<1.9$ Hence, the overall Japanese production function is as follows,

8 Bergsten and Noland (1993) describe how the method of supplier contracting in Japan may increase the proclivity of Japanese assemblers for Japanese parts produced by suppliers with whom they have ongoing arrangements.

9 It is possible that U.S. firms also have a differential efficiency in their use of U.S. and foreign inputs. Incorporation of this idea would only strengthen the conclusions that follow. Further 


$$
Y_{j}=\left[\delta_{\alpha} N_{w} X_{\omega s}^{(1-1 / 0)}+N, X_{j, k}^{(1-1 / \alpha)}\right]^{\frac{1}{1-1 / \sigma}}
$$

Firms maximize profits, taking input prices into consideration. The price of a typical U.S. part is $P_{u s}$, while the price of a representative Japanese part is $P_{j}$. In light of the production technology, the respective demands for U.S. inputs by Japanese and U.S. producers in the U.S. are:

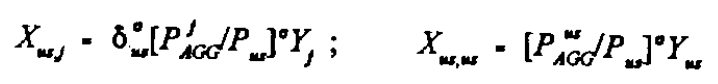

At the same time, the demand for Japanese inputs by Japanese and U.S. producers in the U.S. are determined by:

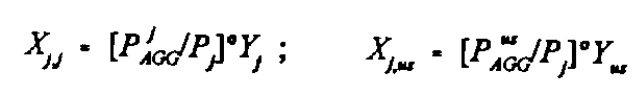

It is important to note that the composite price of inputs $\mathrm{P}_{A G G}$ differs for Japanese and U.S. firms in a fashion that reflects any differential efficiency in the utilization of parts sourced from different locations. In particular, the aggregate price that applies to Japanese parts demand places a weight on U.S. parts prices that is less than or equal to the weight placed on U.S. parts prices by U.S. producers.

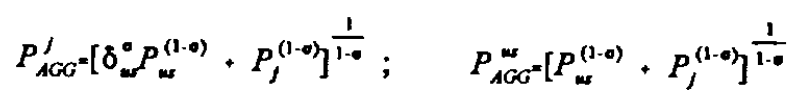

The value of U.S. content in Japanese production depends on the price and variety of U.S. inputs used as well as the quantities of each variety demanded by Japanese producers. We can now compare the value of U.S. input content to the total value of inputs used by Japanese firms through the following calculation:

Explanation of the $\delta_{\mathrm{us}}$ term will be provided in the following section. 


$$
\frac{P_{w} N_{w} X_{w s}}{P_{w} N_{w} X_{w}+P_{j} N_{S} X_{j}}=\frac{8_{w}^{0}}{8_{u}^{0} \cdot\left(N / N_{w}\right)\left(P_{w} / P_{\rho}\right)^{0-1}}
$$

As one would expect, the relative value of U.S. content is rising in the Japanese price of inputs and declining with increases in the U.S. price of inputs. It is important to note as well, that the Japanese price expressed in dollars is generated by the price in Yen multiplied by the exchange rate, $P_{j}=e^{*} P_{j}{ }_{j}^{*}$.

Since a high portion of components purchases are intra-firm in nature, whether the parts are produced in the U.S. or abroad, it is assumed that the parts are priced at marginal cost. It is possible that there are scale economies that are present in the production of intermediate inputs. However, this possibility is excluded here in order to prevent cost feedback that affects total demand. More discussion of product demand is included in the following section.

The U.S. content embodied in U.S. production takes a similar form and prices exert influence in a comparable fashion, and is shown in the final equation.

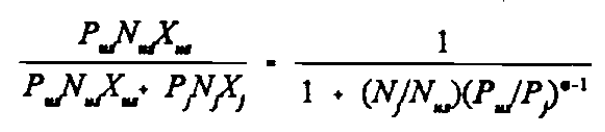

In light of this set of equations, the following conclusions emerge. First, for a given set of Japanese and U.S. prices, the U.S. content of U.S. firm production will be higher than that of Japanese firms. In fact, this conclusion will be exacerbated if U.S. firms use Japanese inputs less efficiently than Japanese firms do, since the preference for own-country inputs will be strengthened. Second, if the dollar depreciates, the domestic content embodied in either U.S. or Japanese production should rise, since dollar depreciations causes the relative price of U.S. inputs to fall.

However, it is possible that Japanese production might not respond to exchange rate movements. 
Japanese motivation for producing in the U.S. could arise from the desire to gain North American content, or desire to circumvent protectionist moves in the U.S. ${ }^{10}$ Additionally, the need to fulfill content requirements for other tariff privileges might also modify the sourcing plans of firms." If so, these motives related to the degree of protection and form of regulation could cause the domestic content of Japanese production to be much higher than the preceding set of equations indicates." If Japan was maintaining a certain level of domestic content in the U.S. to achieve these alternative objectives, then one would expect that the level of U.S. content would not change with exchange rate movements, since content would be held to the minimum threshold needed to satisfy the requirement.

10 This is the situation described by Bhagwati (1987).

11 See Lopez-de-Silanes, Markusen and Rutherford (1993) or Krishna and Krueger (1995) for discussions of content regulations. 


\section{Data and Estimation}

In this section we test the model of parts purchases that was developed in the previous section. It is important to emphasize that the test is one that examines the location from which components are sourced as opposed to the nationality of the party from whom the components are purchased. ${ }^{12}$ In particular, we are seeking to discover the responsiveness of firms in their decision to buy U.S. or foreign parts. In all cases, we are seeking to explain the percentage of total inputs, $\mu$, that are of domestic origin. The first set of tests follow the functional form that is proposed by the model, and are estimated by non-linear least squares. However, the results are subsequently estimated by tobit, in order to examine the sensitivity of the results to functional form, and to augment the regressors.

The preceding section suggests that domestic input content is determined by relative prices of inputs, the variety of inputs, and firm preferences. Hence, the estimating equation that is used in this section assumes the form:

$$
\mu=\frac{\delta_{w j}^{0}}{\delta_{m}^{0} \cdot\left(\frac{N_{f}}{N_{w}}\right)\left(\frac{P_{m}}{P_{j}}\right)^{0-1}}
$$

The relative efficiency of using U.S. parts is measured by $\delta_{u}$. In the case of U.S. headquartered firms, $\delta_{\mathrm{L}}$ is set equal to one. In the case of foreign firms the value of $\delta_{\mathrm{us}}$, is estimated. The relative number of Japanese parts and U.S. parts, $\left(N_{j} / N_{u s}\right)$ is also set equal to one rather than estimated. ${ }^{13}$ Hence, the

12 However Zeile (1995) shows that $94.6 \%$ of automobile firm imports are intra-firm.

13 Attempts were made to estimate the ratio of Japanese to US parts, but the results were too large to be sensible. Also, since there are fully integrated automobile assemblers in both the U.S. and Japan, it seems unlikely that the relative number of part types should differ drastically. 
estimation that proceeds from this point is the determination of the elasticity of substitution and the degree of discount, if any, that foreign producers associate with the use of U.S. parts. The purchase of domestic and foreign inputs is collected from the annual reports of the Foreign Trade Zones Board and is used to construct the measure of domestic content. The price of U.S. parts relative to Japanese parts is proxied alternatively by the relative automotive wage rates in the two countries and by the exchange rate.

\section{Joint Venture Production}

Before continuing, there is one last data issue to be resolved. In particular, there were three international joint ventures by the conclusion of the estimation period. For the purposes of this paper, joint ventures are deemed to be facilities that produce models that are sold under a U.S. and foreign nameplates. ${ }^{14}$ Table 4 experiments with the classification of these U.S./foreign joint ventures to see whether they can be classified as a unique hybrid, or whether these operations are more similar to either U.S. or foreign auto production. Columns (1) and (2) analyze two subsets of the data, and assume that the estimated elasticity of substitution is the same for all types of automaker. In column (1) joint ventures are compared with pure foreign automakers operating in the U.S. The results indicate a slight difference; the pure foreign ventures exhibit an apparent discount on their use of domestic parts relative to the joint venture manufacturers. In column (2) the joint venture producers are compared with U.S. producers. The results suggest that joint venture producers discount the use of U.S. parts relative to the U.S. makers.

Columns (3) and (4) repeat the subset groupings that were tested in the first two columns of table 4. However, the estimation now relaxes the assumption that all automakers have the same elasticity of substitution. Instead, each type of automaker is allowed to have a unique elasticity of substitution.

14 This restrictive definition of joint venture excludes Subaru-Isuzu which involves two Japanese firms. However, none of its output is sold under a U.S. nameplate. 
Column (4) shows that the joint venture producers appear to be less flexible than the U.S. makers, as is shown by their estimated elasticity of substitution of 2.25 . It is shown as well, that the joint venture makers appear to place a discount on U.S. sourced parts relative to the U.S. firms.

Finally, the entire sample is tested in columns (5) and (6) of table 4. Here each type of firm is allowed to have its own elasticity of substitution in its purchasing of parts. In column (5) it is assumed that no discount applies to the foreign purchase of U.S. parts. This column shows that U.S. firms have an estimated elasticity of substitution that is more than $50 \%$ larger than the estimated elasticity of foreign or joint venture firms. In column (6), it is assumed that foreign firms, and joint ventures have a common elasticity of substitution, but that they may have different discount rates in their use of U.S. parts. Again, the estimated elasticity for U.S. firms is much higher that than that for the foreign or joint venture firms in the sample. On the other hand, the estimated discount factors of foreign and joint venture operators are very close in magnitude. Since the joint venture firms have elasticities that are similar in magnitude to the pure foreign firm elasticities, the following estimation assumes that the foreign firm and joint venture observations can be classified together as foreign. The specification further assumes that foreign and joint venture producers have the same discount factor in their use of U.S. parts.

Table 4A investigates a number of subsets in the data, in order to gauge whether any of the factors provide meaningful insight into the estimated elasticities of substitution or the input discount factor, 8. Columns (1) and (2) separate the assembly zones from zones that specialize in the production of parts. Although the elasticity of substitution for U.S. firms is virtually identical to the previous estimates, the results show that foreign or joint venture assemblers have a higher elasticity of substitution than was estimated in the previous table. However, a differential still remains.

Columns (3) and (4) distinguish the auto assemblers by production volume. Auto zones producing 207,000 or more vehicles per calendar year were deemed high volume, and zones producing 
fewer vehicles were classified as low volume. Auto firms are broken out according to production volume, since the auto industry is known for its high fixed costs of production. We might assume that a firm with high production volume would be more sensitive to cost changes than a low volume firm, since the low volume firm could not justify producing parts in multiple locations, even if relative prices changed. This reluctance would be most pronounced in the case of engine or transmission production, where fixed costs are especially high causing a reliance on scale production.

Data on automobile zone volume was collected by matching each foreign trade zone with the auto plant data published in the Automotive News, Market Data Book. During the sample period, the median U.S. assembly site plant (both foreign trade zone, and non-foreign trade zone) produced 207,000 vehicles. Of those plants producing within a zone, the median number of vehicles produced was $227,000 .^{15}$ These results suggest that foreign and domestic assemblers have similar elasticities of substitution, but that the notable differences emerge from the low volume sample. In the low volume sample U.S. firms are much more responsive to price changes than are foreign producers in the U.S.

Finally the data are separated according to the number of nameplate vehicle types produced in each zone. This rationale for this separation is to see whether the difference in foreign and domestic elasticities relates to the fact that foreign zones typically produce fewer car models in each zone than do U.S. producers. Column (5) includes all assemblers who produce 3 or more vehicle types in a zone, where column (6) includes all those with 2 or less vehicle nameplates. Vehicle diversity can not be excluded as a determinant of U.S. foreign differences. However, the imprecision of the estimated foreign elasticity makes it difficult to draw conclusions as to whether production diversity plays a role.

15 The numbers are different, because some firms were slower to open zones than others. 


\section{Tobit Estimates}

Although the previous estimates have the advantage of following directly from the model of parts demand, and result in direct estimates of the elasticity of substitution, they suffer from a few drawbacks. The main reasons for using tobit analysis here is to see how estimated domestic content responds to price changes when a larger set of firm characteristics is considered. It is true that the elasticity of demand could be estimated as a function of plant age or other characteristics. However, results were not stable or precisely estimated when this was performed with this paper's data set. The estimating equation now takes the form:

$$
\mu=\alpha+\alpha_{u s}-\beta^{*} \mathrm{e}+\gamma \mathrm{X}+\xi
$$

As before, content varies over time as relative prices change. These price change are captured alternatively by exchange rate movements, measured by $e$, and later by the direct measurement of factor input prices. Now, however, the level of U.S. content in production also depends on a U.S. shift term, $\alpha_{u s}$, and firm characteristics X. The error term is measured by $\xi$.

Table 5 provides a baseline estimate in column (1). As expected, the results show that the average U.S. firm utilizes $31.5 \%$ more domestic value added than does the average foreign firm. This baseline estimate assumes further that all firms react similarly to exchange rate movements, and the estimated effect again confirms that dollar depreciation causes the share of U.S. inputs to rise. Column (2) adds another indicator variable to capture differences between parts makers and assemblers. While the results are qualitatively similar to the baseline estimates, the estimation finds that parts makers have domestic content that is roughly $16 \%$ lower than that of assemblers.

Column (3) introduces the possibility that foreign and domestic firms may have different responses to the movement of the exchange rate, and actually suggests that the response is higher for the foreign firms in the sample. The specification also includes measures of the zone's age, where age is the number of years of zone operation. The age variable used applies only to the case of foreign 
firms. When age was included more generally, the estimated effects varied substantially and were not precisely estimated. It is likely that the age of the subzone activity is more meaningful in the case of foreign operations since they are more recently opened. Here we find that foreign firms source an increasing portion of their parts from the U.S. as their zones age, but that the level of growth diminishes over time.

Column (4) adds another control for the total shipment size of the zones. It is learned that zones with higher shipments use a greater percentage U.S. parts. The inclusion of this regressor brings the value of the foreign response to the exchange rate back down to a magnitude that is slightly smaller than that of U.S. firms. Finally column (5) estimates firm fixed effects. The results are qualitatively similar to the previous specification. Overall, the results suggest that many of the observed differences between foreign and U.S. firms are caused by age and production volume differences.

Rather than relying solely on the exchange rate to proxy for relative price effects, we now work with specifications that include a number of prices that should directly affect the costs of production in the auto industry. Table $5 \mathrm{~A}$ sequentially adds measures of ore costs and energy costs to the estimating equations. Each of the results implies that a rise in the relative cost of labor in the U.S. will reduce the domestic content of U.S. produced automobiles. In contrast, relative energy and iron prices enter with a perverse positive coefficient. This suggests that the use of domestic inputs relative to total inputs increases when the U.S. prices of these inputs rise. However, none of these estimates are significant. And importantly, the continued U.S. indicator variable shows that U.S. firms utilize $30 \%$ greater levels of domestic inputs, even after controls have been added for input prices. It is the relative price of labor that plays the most decisive role in parts sourcing decisions.

\section{Specification Checks}

Table 6 examines the tobit estimating assumption that the regression errors are homoskedastic. Since the errors could be related to firm size, the first two columns divide the dependent variable, 
percentage domestic content, first by the square root of shipment size and next by the square root of zone production volume. While the first normalization provides results that are qualitatively similar to earlier tobit analysis, the second, based on production volume, does not. A further difference between columns (1) and (2) is that production volume only applies to auto assemblers who produce completed vehicles. Since total shipments represents the dollar value of shipments, it includes parts makers and assemblers. Under the assumption that there will be less heteroskedasticity of errors if data are analyzed according to production volume subsets, the tobit analysis is redone on subsamples of the data that are classified as high or low volume. As was learned previously, in the nonlinear least squares estimates, the biggest apparent differences appear when low volume producers are compared. However, this result is sensitive to the volume classification selected; median of all auto production, or median of all foreign trade subzone production. Nonetheless, in three of the four estimates of price responsiveness in columns (3) - (6), U.S. firms exhibit greater sensitivity in all but column (5). And this result is robust to the inclusion of firm age effects, which were found to affect the price responsiveness. 


\section{Conclusions}

This paper studies the domestic content decisions of domestic and foreign auto makers in the U.S. between 1984 and 1993. The results show that although the domestic content of Japanese firms has risen over time, differences are not being eliminated completely. Also, the apparent elasticity of substitution is lower for Japanese than for U.S. firms. If one assumes that the demand for Japanese nameplate automobiles will remain roughly constant, regardless of assembly location, these results suggest that although transplant production may reduce the U.S. automotive deficit with Japan, that transplant production will not cause its elimination.

The fact that the relative domestic input content of automakers responds to relative production costs provides two implications for multinational activity. To begin, this sensitivity to relative costs suggests that foreign automakers are not purely motivated by the goal of circumventing U.S. trade restrictions. If this were the single reason for transplant activity in the U.S., we would expect the degree of U.S. content to be kept to a minimum that would not change with external conditions. Next, some studies such as Klein and Rosengren (1994) claim that foreign investment outlays are not measurably altered by movements in relative wages. It may be true that foreign investment outlays do not respond to relative wage movements, but it would be incorrect to infer that no other real activities were affected. These results suggest that real wage movements may nonetheless have important consequences, since multinationals can adjust their activities along other margins such as domestic versus foreign content. Further work is needed to provide an integrated understanding of the various margins along which multinational activity is conducted. 


\section{Bibliography}

Bergsten, C. Fred, and Marcus Noland (1993). Reconcilable Differences? United States-Japan Economic Conflict, Washington D.C.: Institute for International Economics.

Bhagwati, Jagdish N. (1987) "Quid Pro Quo DFI and VIEs: A Political-Economy-Theoretic Analysis," International Economic Journal, vl(1), 1-14.

Blomstrom, Magnus, Robert E. Lipsey and Ksenia Kulchycky. (1988) "U.S. and Swedish Direct Investment and Exports," in Trade Policy Issues and Empirical Analysis, Robert E. Baldwin, ed. Chicago: The University of Chicago Press, 259-297.

Brainard, Lael S. (1993). "An Empirical Assessment of the Proximity-Concentration Tradeoff Between Multinational Sales and Trade." NBER Working Paper, \#4580, December.

Ethier, Wilfred J. (1986). "The Multinational Firm," Quarterly Journal of Economics, 101:805-833.

Finger, J.M., (1976). "Trade and Domestic Effects of the Offshore Assembly Provision in the U.S. Tariff," American Economic Review, 66:598-611.

Foreign Trade Zones Board. "Annual Report to the Congress of the United States," 1984-1992.

Giovannini, Alberto, (1988). "Exchange Rates and Traded Goods Prices," Journal of International Economics, 24:45-68.

Grossman, Gene M. (1981). "A Theory of Domestic Content Protection and Preference," Quarterly Journal of Economics, 96(4):583-603.

Grossman, Gene M. (1982). "Offshore Assembly Provisions and the Structure of Protection," Journal of International Economics, 12:301-312.

Helpman, Elhanan, (1984). "A Simple Theory of International Trade with Multinational Corporations," Journal of Political Economy, 92:451-471.

Horstmann, I.J. and J.R. Markusen, (1992). "Endogenous Market Structure in lnternational Trade (natura facit saltum)," Journal of International Economics, 32:109-129.

Klein, Michael W. and Eric Rosengren, (1994). "The Real Exchange Rate and Foreign Direct Investment in the United States: Relative Wealth vs. Relative Wage Effects," Journal of International Economics, 36:373-389.

Krishna, Kala and Anne Krueger, (1995). "Implementing Free Trade Areas: Rules of Origin and Hidden Protection," NBER Working Paper, \#4983, January. 
Lopez-de-Silanes, Florencio, James R. Markusen and Thomas F. Rutherford, (1993). "Anti-Competitive and Rent-Shifting Aspects of Domestic-content Provisions in Regional Trade Blocks," NBER Working
Paper, \#4512.

Mendez, Jose A. (1993). "The Welfare Effects of Repealing the Offshore Assembly Provision," Journal of International Economics, 34:1-22.

United States House of Representatives, 1989. "Foreign Trade Zones," Hearing before the Commerce, Consumer, and Monetary Affairs Subcommittee of the Committee on Government Operations, March 7, Washington: U.S. Government Printing Office.

Wells, Louis T., Jr. (1992), "Conflict or Indifference: US Multinationals in a World of Regional Trading Blocs," Organization for Economic Cooperation and Development, Research Program on Globalization and Regionalisation, Technical Paper, No. 57, Paris: OECD. 
Table 1: U.S. Content and U.S. Shipments of FTZ Subzone Auto Assemblers.

\begin{tabular}{|c|c|c|c|c|c|c|}
\hline \multirow[b]{2}{*}{ Year } & \multicolumn{4}{|c|}{ U.S. Firms } & \multicolumn{2}{|c|}{$\underline{\text { Foreign Firms }}$} \\
\hline & $\begin{array}{l}\# \\
\text { Sites }\end{array}$ & $\begin{array}{l}\% \text { Domestic } \\
\text { Shipments }\end{array}$ & $\begin{array}{l}\% \text { Domestic } \\
\text { lnputs }\end{array}$ & $\begin{array}{l}\# \\
\text { Sites }\end{array}$ & $\begin{array}{l}\% \text { Domestic } \\
\text { Shipments }\end{array}$ & $\begin{array}{l}\% \text { Domestic } \\
\text { Inputs }\end{array}$ \\
\hline 1984 & 9 & 90.3 & 90.6 & 3 & 96.0 & 35.1 \\
\hline 1985 & 15 & 90.8 & 91.5 & 5 & 96.9 & 32.0 \\
\hline 1986 & 20 & 92.1 & 90.5 & 5 & 97.3 & 29.2 \\
\hline 1987 & 22 & 92.1 & 91.3 & 4 & 98.5 & 41.3 \\
\hline 1988 & 25 & 91.8 & 88.6 & 5 & 95.2 & 49.3 \\
\hline 1989 & 29 & 90.1 & 87.6 & 6 & 94.4 & 52.8 \\
\hline 1990 & 29 & 91.6 & 91.0 & 6 & 93.8 & 59.6 \\
\hline 1991 & 28 & 93.4 & 95.0 & 6 & 92.6 & 64.1 \\
\hline 1992 & 28 & 93.2 & 95.9 & 6 & 89.8 & 68.8 \\
\hline 1993 & 28 & 91.8 & 95.4 & 6 & 88.5 & 66.7 \\
\hline
\end{tabular}

Notes: \% Domestic Shipment is the percentage of shipments from the foreign trade subzone that is shipped to U.S. destinations. \% Domestic Inputs is the percentage of inputs entering the foreign trade subzone from U.S. locations. The percentages have been weighted by zone shipments.

Source: Foreign Trade Zones Board, Annual Reports, and author's calculations. 


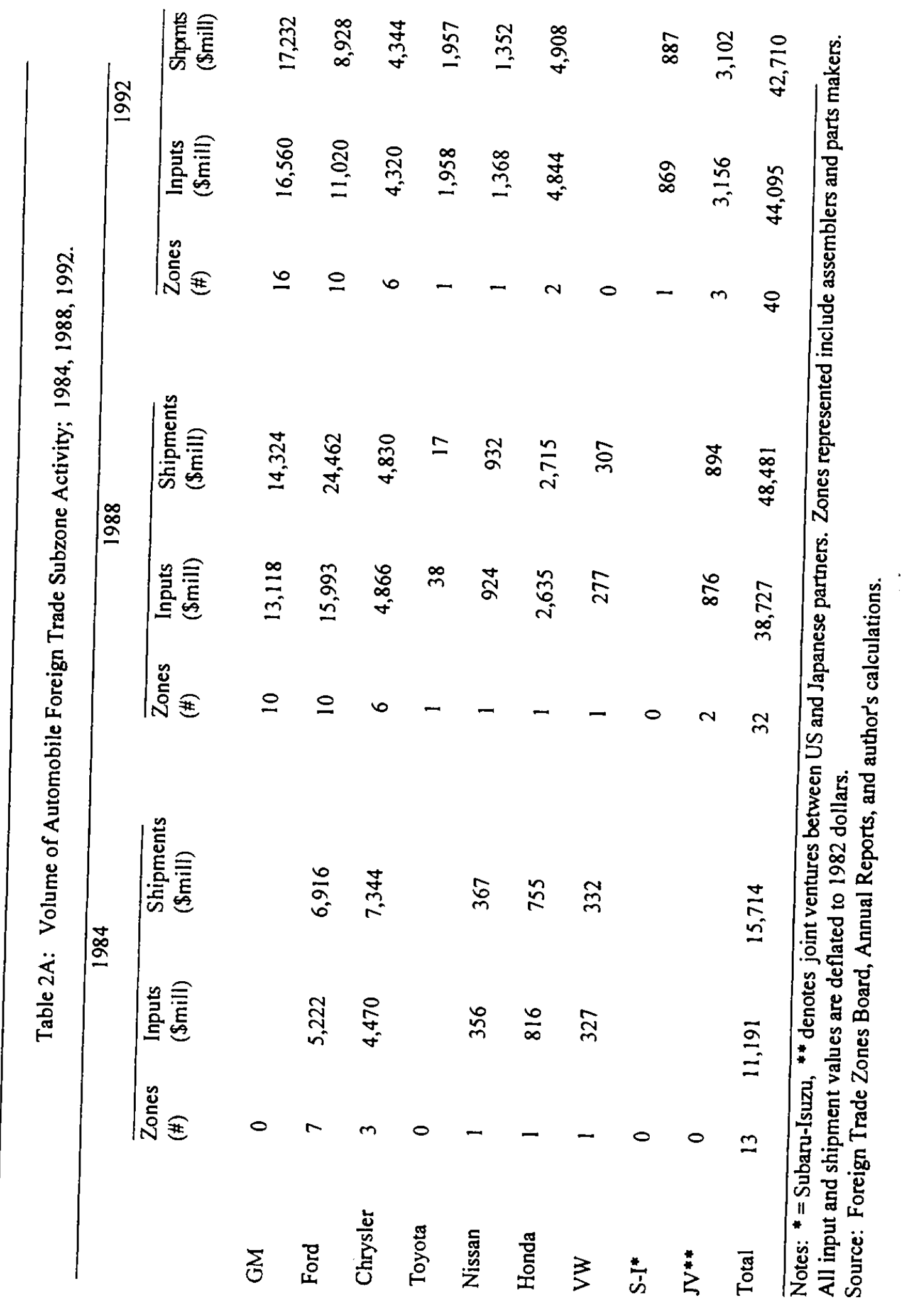




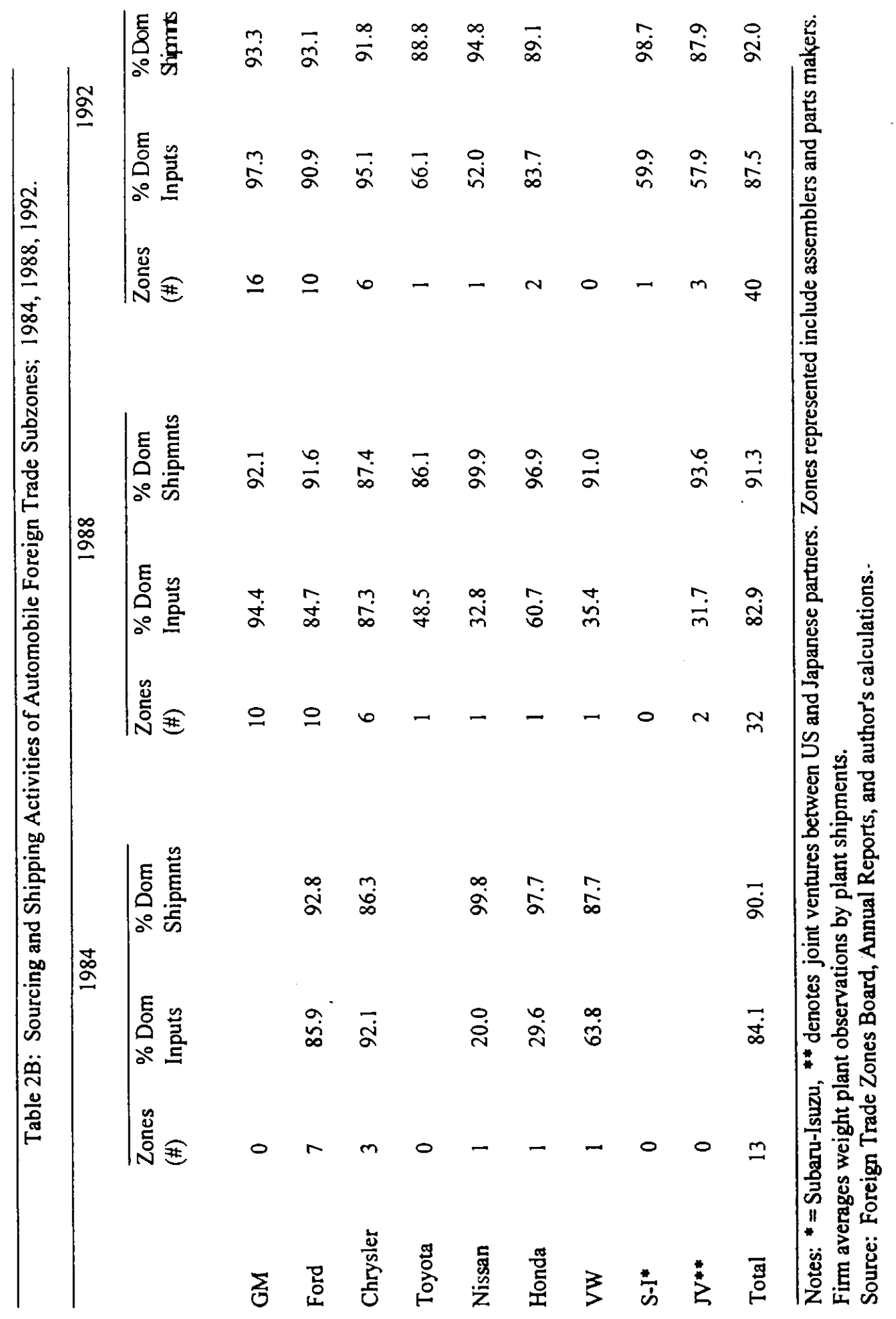




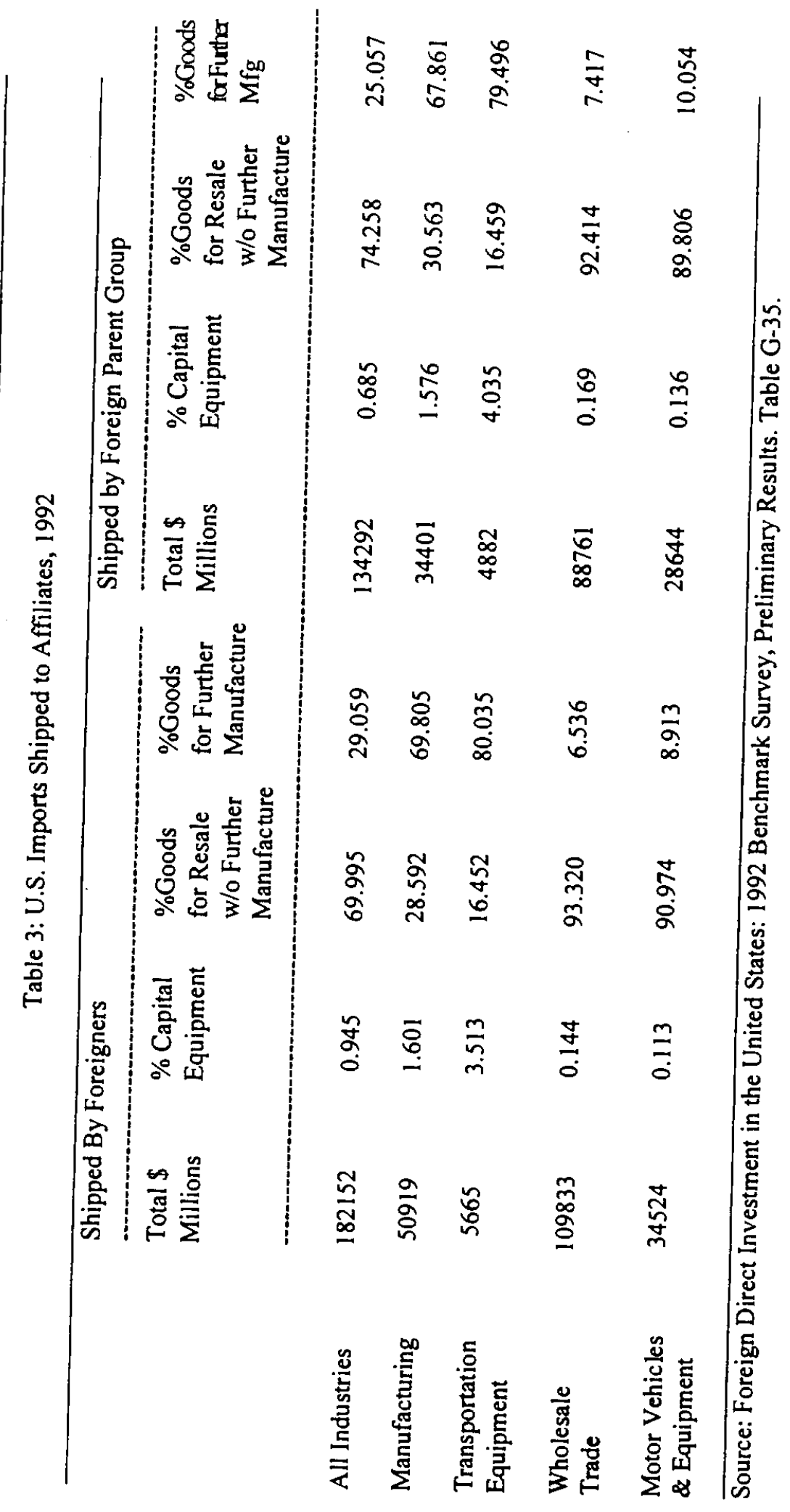




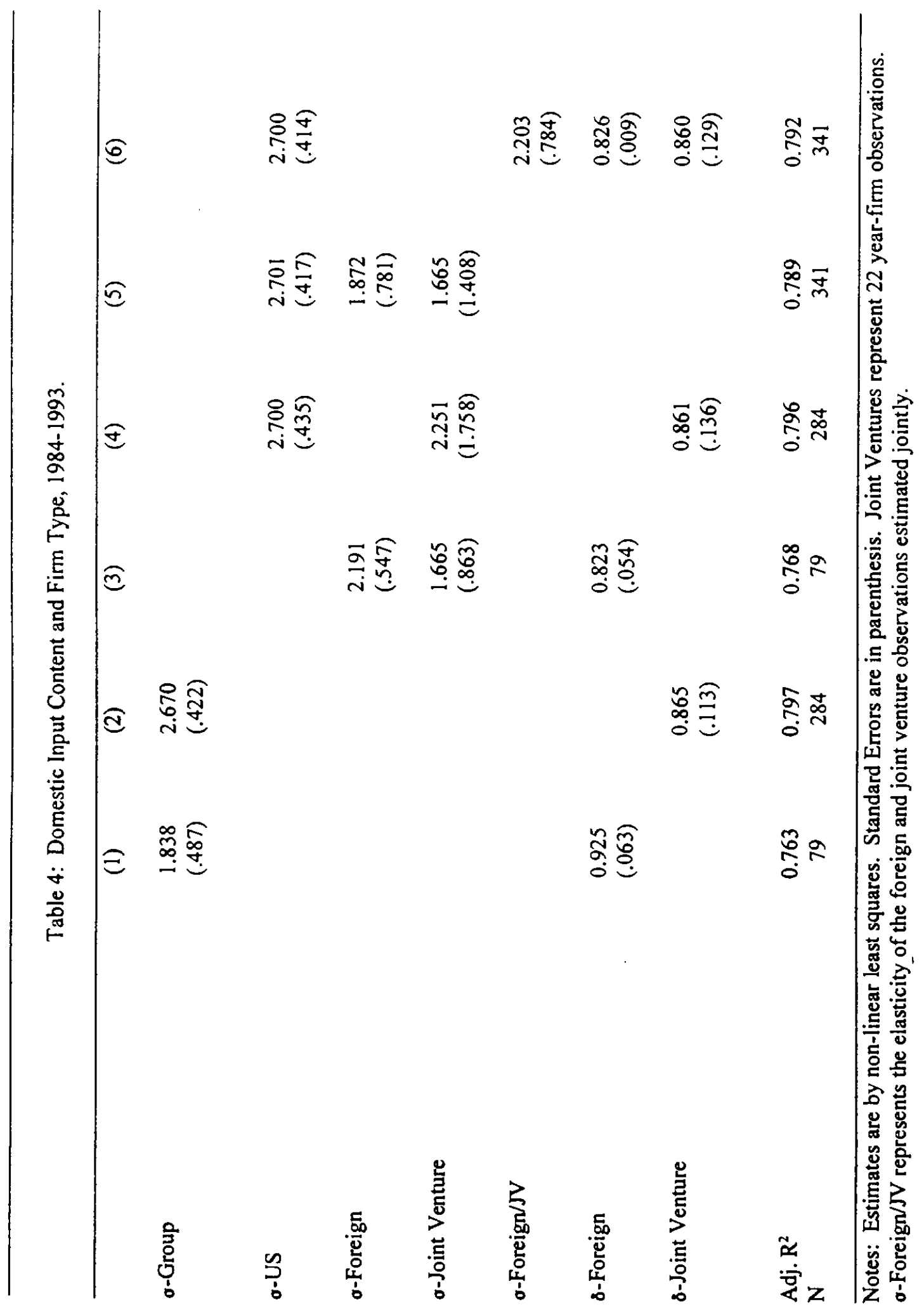




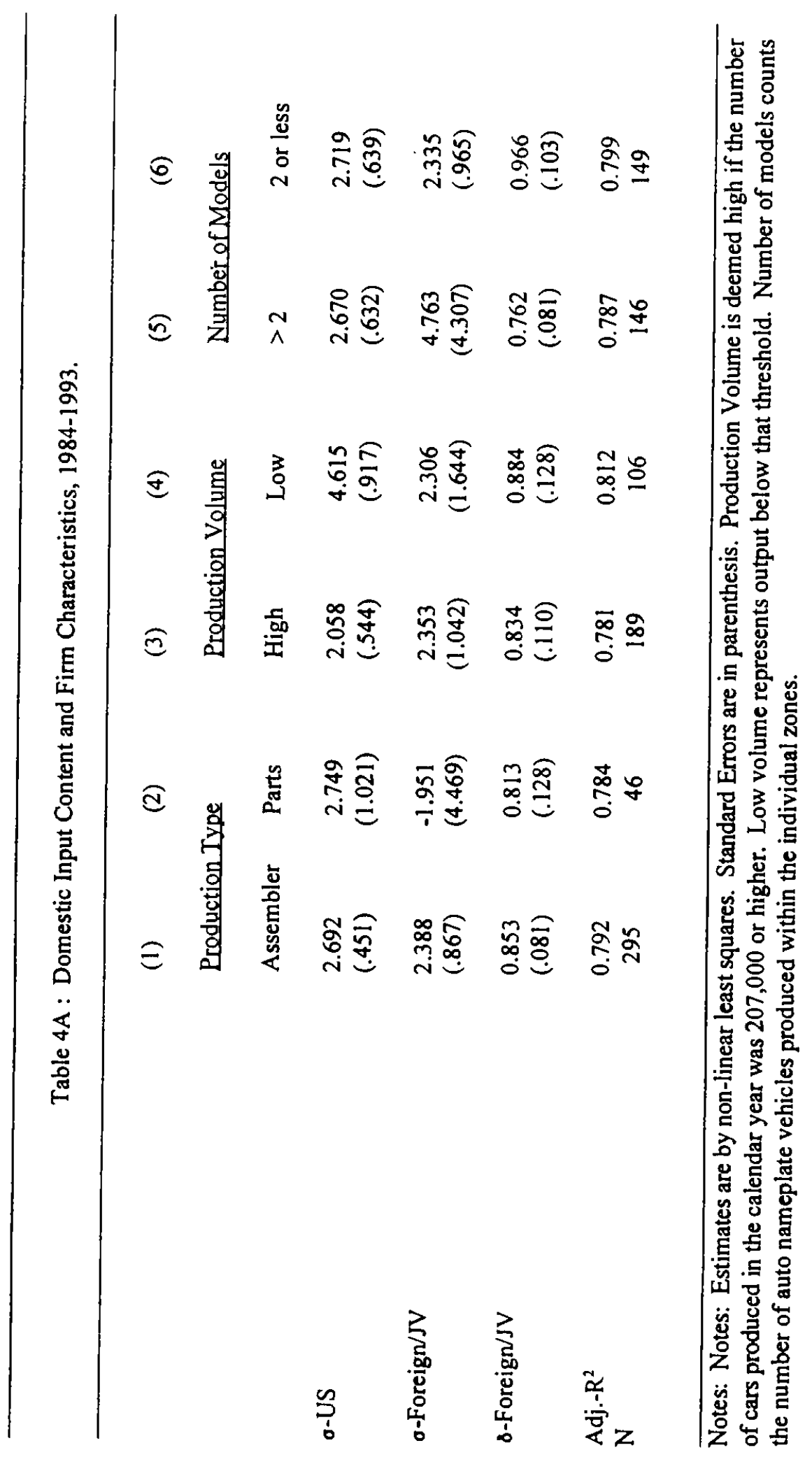


Table 5: Auto Production in U.S. Foreign Trade Zones, 1984-1993 Dependent Variable: [Domestic lnputs / Total Inputs]

\begin{tabular}{|c|c|c|c|c|c|}
\hline & (1) & (2) & (3) & (4) & (5) \\
\hline US & $\begin{array}{c}0.315 \\
(0.028)\end{array}$ & $\begin{array}{c}0.294 \\
(0.027)\end{array}$ & $\begin{array}{l}0.204 \\
(0.850)\end{array}$ & $\begin{array}{c}0.588 \\
(0.831)\end{array}$ & \\
\hline Parts & & $\begin{array}{l}-0.161 \\
(0.035)\end{array}$ & $\begin{array}{l}-0.146 \\
(0.033)\end{array}$ & $\begin{array}{l}-0.099 \\
(0.034)\end{array}$ & $\begin{array}{l}-0.200 \\
(0.030)\end{array}$ \\
\hline $\log$ (exch rate) & $\begin{array}{l}-0.162 \\
(0.094)\end{array}$ & $\begin{array}{l}-0.218 \\
(0.092)\end{array}$ & & & \\
\hline $\begin{array}{l}\text { Log(exch rate) } \\
{ }^{*} \text { US }\end{array}$ & & & $\begin{array}{l}-0.233 \\
(0.090)\end{array}$ & $\begin{array}{l}-0.254 \\
(0.088)\end{array}$ & $\begin{array}{l}-0.135 \\
(0.068)\end{array}$ \\
\hline $\begin{array}{l}\text { Log(exch rate) } \\
\text { *Foreign }\end{array}$ & & & $\begin{array}{l}-0.318 \\
(0.171)\end{array}$ & $\begin{array}{l}-0.245 \\
(0.167)\end{array}$ & $\begin{array}{l}-0.135 \\
(0.070)\end{array}$ \\
\hline $\begin{array}{l}\text { Age } \\
*_{\text {foreign }}\end{array}$ & & & $\begin{array}{c}0.088 \\
(0.010)\end{array}$ & $\begin{array}{c}0.081 \\
(0.010)\end{array}$ & $\begin{array}{c}0.012 \\
(0.010)\end{array}$ \\
\hline $\begin{array}{l}\text { Age }^{2} \\
\text { *Foreign }\end{array}$ & & & $\begin{array}{l}-0.005 \\
(0.007)\end{array}$ & $\begin{array}{l}-0.005 \\
(0.001)\end{array}$ & $\begin{array}{c}0.0001 \\
(0.0007)\end{array}$ \\
\hline $\begin{array}{l}\text { Total } \\
\text { Shipments }\end{array}$ & & & & $\begin{array}{l}0.005 \\
(0.001)\end{array}$ & $\begin{array}{c}0.002 \\
(0.001)\end{array}$ \\
\hline Constant & $\begin{array}{r}1.257 \\
(0.428)\end{array}$ & $\begin{array}{l}1.544 \\
(0.421)\end{array}$ & $\begin{array}{c}1.724 \\
(0.791)\end{array}$ & $\begin{array}{l}1.365 \\
(0.773)\end{array}$ & $\begin{array}{c}1.204 \\
(0.313)\end{array}$ \\
\hline Firm Effects & NO & NO & NO & NO & YES \\
\hline $\mathrm{N}$ & 341 & 341 & 341 & 341 & 341 \\
\hline $\begin{array}{l}\text { Log } \\
\text { Likelihood }\end{array}$ & 16.55 & 26.47 & 60.28 & 69.80 & 156.51 \\
\hline
\end{tabular}

Note: Standard errors in parentheses. 
Table 5A: Auto Production in U.S. Foreign Trade Zones, 1984-1993

Dependent Variable: [Domestic Inputs / Total Inputs]

\begin{tabular}{|c|c|c|c|c|}
\hline & (1) & (2) & (3) & (4) \\
\hline US & $\begin{array}{c}0.316 \\
(0.028)\end{array}$ & $\begin{array}{c}0.316 \\
(0.028)\end{array}$ & $\begin{array}{l}0.323 \\
(0.028)\end{array}$ & $\begin{array}{c}0.304 \\
(0.027)\end{array}$ \\
\hline $\begin{array}{l}\text { Relative } \\
\text { Wage }\end{array}$ & $\begin{array}{l}-0.079 \\
(0.051)\end{array}$ & $\begin{array}{l}-0.088 \\
(0.056)\end{array}$ & $\begin{array}{l}-0.061 \\
(0.059)\end{array}$ & $\begin{array}{l}-0.083 \\
(0.058)\end{array}$ \\
\hline $\begin{array}{l}\text { Relative } \\
\text { Energy Cost }\end{array}$ & & $\begin{array}{l}0.003 \\
(0.171)\end{array}$ & $\begin{array}{c}0.0002 \\
(0.170)\end{array}$ & $\begin{array}{l}-0.073 \\
(0.165)\end{array}$ \\
\hline $\begin{array}{l}\text { Relative Iron } \\
\text { Cost }\end{array}$ & & $\begin{array}{c}0.049 \\
(0.079)\end{array}$ & $\begin{array}{c}0.050 \\
(0.079)\end{array}$ & $\begin{array}{l}0.053 \\
(0.076)\end{array}$ \\
\hline $\begin{array}{l}\text { Relative Wage } \\
\text { *Foreign }\end{array}$ & & & $\begin{array}{l}-0.141 \\
(0.111)\end{array}$ & $\begin{array}{l}-0.213 \\
(0.108)\end{array}$ \\
\hline Parts & & & & $\begin{array}{l}-0.176 \\
(0.036)\end{array}$ \\
\hline constant & $\begin{array}{c}0.514 \\
(0.026)\end{array}$ & $\begin{array}{r}0.500 \\
(0.034)\end{array}$ & $\begin{array}{c}0.494 \\
(0.035)\end{array}$ & $\begin{array}{c}0.530 \\
(0.034)\end{array}$ \\
\hline$N$ & 341 & 341 & 341 & 341 \\
\hline $\begin{array}{l}\text { Log-L } \\
\text { Likelihood }\end{array}$ & 16.24 & 16.46 & 17.27 & 28.66 \\
\hline
\end{tabular}

Note: Standard errors in parentheses. 


\begin{tabular}{|c|c|c|c|c|c|c|}
\hline & \multirow[b]{2}{*}{ (1) } & \multirow[b]{2}{*}{ (2) } & \multicolumn{2}{|c|}{ High Volume } & \multicolumn{2}{|c|}{ Low Volume } \\
\hline & & & (3) & (4) & (5) & (6) \\
\hline US & $\begin{array}{c}0.09 \\
(0.22)\end{array}$ & $\begin{array}{l}-0.01 \\
(0.02)\end{array}$ & $\begin{array}{c}0.63 \\
(0.22)\end{array}$ & $\begin{array}{c}0.60 \\
(0.23)\end{array}$ & $\begin{array}{c}0.61 \\
(0.24)\end{array}$ & $\begin{array}{c}0.32 \\
(0.18)\end{array}$ \\
\hline $\begin{array}{l}\text { Real* } \\
\text { US }\end{array}$ & $\begin{array}{l}-0.23 \\
(0.12)\end{array}$ & $\begin{array}{c}0.01 \\
(0.01)\end{array}$ & $\begin{array}{l}-0.29 \\
(0.16)\end{array}$ & $\begin{array}{l}-0.31 \\
(0.18)\end{array}$ & $\begin{array}{l}-0.20 \\
(0.20)\end{array}$ & $\begin{array}{l}-0.47 \\
(0.14)\end{array}$ \\
\hline $\begin{array}{l}\text { Real }{ }^{*} \\
\text { Foreign }\end{array}$ & $\begin{array}{l}-0.16 \\
(0.17)\end{array}$ & $\begin{array}{l}-0.01 \\
(0.02)\end{array}$ & $\begin{array}{l}-0.13 \\
(0.12)\end{array}$ & $\begin{array}{l}-0.12 \\
(0.13)\end{array}$ & $\begin{array}{l}-0.18 \\
(0.09)\end{array}$ & $\begin{array}{l}-0.20 \\
(0.08)\end{array}$ \\
\hline Age & $\begin{array}{l}-0.01 \\
(0.01)\end{array}$ & $\begin{array}{l}0.001 \\
(0.0004)\end{array}$ & $\begin{array}{l}-0.02 \\
(0.01)\end{array}$ & $\begin{array}{l}-0.02 \\
(0.01)\end{array}$ & $\begin{array}{l}-0.004 \\
(0.005)\end{array}$ & $\begin{array}{l}-0.005 \\
(0.005)\end{array}$ \\
\hline $\begin{array}{l}\text { Foreign* } \\
\text { Age }\end{array}$ & $\begin{array}{l}-0.05 \\
(0.03)\end{array}$ & $\begin{array}{l}-0.003 \\
(0.002)\end{array}$ & $\begin{array}{c}0.06 \\
(0.03)\end{array}$ & $\begin{array}{c}0.07 \\
(0.03)\end{array}$ & $\begin{array}{c}0.07 \\
(0.03)\end{array}$ & $\begin{array}{c}0.04 \\
(0.02)\end{array}$ \\
\hline $\begin{array}{l}\text { Foreign* } \\
\text { Age2 }\end{array}$ & $\begin{array}{c}0.003 \\
(0.002)\end{array}$ & $\begin{array}{l}0.0001 \\
(0.0002)\end{array}$ & $\begin{array}{c}0.001 \\
(0.002)\end{array}$ & $\begin{array}{l}0.0001 \\
(0.002)\end{array}$ & $\begin{array}{l}-0.005 \\
(0.002)\end{array}$ & $\begin{array}{l}-0.002 \\
(0.002)\end{array}$ \\
\hline Constant & $\begin{array}{c}0.50 \\
(0.18)\end{array}$ & $\begin{array}{c}0.03 \\
(0.02)\end{array}$ & $\begin{array}{c}0.44 \\
(0.17)\end{array}$ & $\begin{array}{c}0.45 \\
(0.18)\end{array}$ & $\begin{array}{c}0.51 \\
(0.22)\end{array}$ & $\begin{array}{c}0.81 \\
(0.16)\end{array}$ \\
\hline $\begin{array}{l}\text { Log } \\
\text { Likelihood }\end{array}$ & 10.88 & 1262.25 & 56.41 & 47.99 & 110.94 & 123.41 \\
\hline$N$ & 340 & 242 & 232 & 219 & 109 & 122 \\
\hline
\end{tabular}

